

\title{
The education pillar of the Europe 2020 strategy: A convergence analysis
}

\author{
Juan Carlos Cuestas \\ Universitat Jaume I \\ IEI \& Department of Economics \\ cuestas@uji.es
}

\author{
Mercedes Monfort \\ Universitat Jaume I
}

IEI \& Department of Economics

mmonfort@uji.es

\author{
Javier Ordóñez \\ Universitat Jaume I \\ IEI \& Department of Economics \\ javier.ordonez@uji.es
}

\section{$2020 / 06$}

\begin{abstract}
In March 2010, the European Commission launched the Europe 2020 strategy 'for smart, sustainable and inclusive growth' in the EU. Education is a major pillar of Europe 2020 strategy due to its long-run impact on economic growth, productivity, and social cohesion. The Europe 2020 strategy established two headline targets on early leavers from education and training and tertiary educational attainment at the EU level. This paper attempts to assess the Europe 2020 strategy for the education pillar in terms of convergence across countries. Despite the fact that every country in the EU has its own national targets in these two headline indicators, progress on the achievement of the Europe 2020 strategy requires convergence. Thus, even if the EU as a whole meets its targets in 2020, the existence of a growing divide between the best and worst performing countries would cast doubt on the prospects of real economic convergence and the sustainability of the process. Our empirical findings reveal the existence of convergence clubs in educational attainment and the early leavers rate, and points towards the idea of multi-speed transitional dynamics in Europe, calling into question the convergence in educational performance in the EU.
\end{abstract}

Keywords: education, human capital, convergence, Europe

JEL classification: C22, F15 


\title{
The education pillar of the Europe 2020 strategy: a convergence analysis
}

\author{
Juan Carlos Cuestas \\ Department of Economics and IEI \\ University Jaume I \\ Mercedes Monfort \\ Department of Economics and IEI \\ University Jaume I \\ Javier Ordóñez* \\ Department of Economics and IEI \\ University Jaume I
}

\begin{abstract}
In March 2010, the European Commission launched the Europe 2020 strategy 'for smart, sustainable and inclusive growth' in the EU. Education is a major pillar of the Europe 2020 strategy due to its long-run impact on economic growth, productivity, and social cohesion. The Europe 2020 strategy established two headline targets on early leavers from education and training and tertiary educational attainment at the EU level. This paper attempts to assess the Europe 2020 strategy for the education pillar in terms of convergence across countries. Despite the fact that every country in the EU has its own national targets in these two headline indicators, progress on the achievement of the Europe 2020 strategy requires convergence. Thus, even if the EU as a whole meets its targets in 2020, the existence of a growing divide between the best and worst performing countries would cast doubt on the prospects of real economic convergence and the sustainability of the process. Our empirical findings reveal the existence of convergence clubs in educational attainment and the early leavers rate, and points towards the idea of multi-speed transitional dynamics in Europe, calling into question the convergence in educational performance in the EU.
\end{abstract}

Key words: education; human capital; convergence; Europe.

JEL code: C22, F15.

\begin{abstract}
Acknowledgements
Javier Ordóñez acknowledges the MINEIC-AEI-FEDER ECO2017-83255-C3-3-P project, both of which are from the 'Ministerio de Economía, Industria y Competitividad' (MINEIC), 'Agencia Estatal de Investigación' (AEI) Spain and 'Fondo Europeo de Desarrollo Regional' (FEDER). Javier Ordóñez and Mercedes Monfort are grateful for support from the University Jaume I research project UJI-B2017-33. Javier Ordóñez also acknowledges the Generalitat Valenciana project PROMETEO/2018/102.
\end{abstract}

*Corresponding author. Email: javier.ordonez@uji.es Address for correspondence: Department of Economics, Universitat Jaume I, Avda Sos Baynat s.n, 12070 Castellón de la Plana, Spain. 


\section{Introduction}

In March 2010, the European Commission launched the Europe 2020 strategy 'for smart, sustainable and inclusive growth' (European Commission, 2020) in the EU to prepare the integrated area for the challenges of the next decade. The strategy aims to foster a high-employment economy, as well as promoting productivity and a more competitive economy based on knowledge and innovation. The ultimate objective is to deliver social and territorial cohesion in the Member States while reducing the impact on the natural environment through a more resource-efficient and greener economy. These objectives are defined in terms of eight targets in the areas of employment, research and development, climate change and energy, education and poverty reduction. A set of nine headline indicators and additional sub-indicators enable the monitoring of progress towards the overall targets and an assessment of how far the EU still has to go to reach them.

Education is a major pillar of the Europe 2020 strategy due to its long-run impact on economic growth, productivity, and socio-economic cohesion, promoting social mobility and the reduction of personal income inequalities. The Europe 2020 strategy established two headline targets on early leavers from education and training and tertiary educational attainment at the EU level: the share of early school leavers should be under $10 \%$ and at least $40 \%$ of the younger generation should have a tertiary degree. These goals are translated into national targets to tailor the Europe 2020 strategy to the particular circumstances of each Member State. Later, five more headline targets were included in the strategic framework for European cooperation in education and training, or ET 2020.

Economists have proposed many channels through which education may affect economic growth and productivity. The first strand of the literature focuses on the individual who chooses the amount to invest in education so as to maximise her expected discounted value of lifetime utility (Becker, 1964, Heckman, 1976, Keane and Wolpin, 1997). Becker and Tomes $(1979,1986)$ were the first to suggest that the education investment depends not only on the intertemporal maximisation of profits but also on the socio-economic background of the family. Wealthy families are not credit constrained, meaning they are able to borrow to finance the optimal investment in their children's education (Acemoglu and Pischke, 2001, Black and Deveraux, 2011). Education is also positively related to growth through a variety of externalities. Education investment fosters technological innovation, making both capital and labour more productive, generating income growth (Mankiw et al., 1992). Early-leavers from education have to endure longer periods before finding a job and, when hired, their jobs often lack long-term security and offer low wages and poor training (Furlong, 2006), decreasing their productivity and reducing their prospects of social mobility.

The immediate predecessor of the Europe 2020 strategy was the Lisbon Strategy, established in March 2000, with the goal of transforming the EU into 'the most competitive and dynamic knowledge-based economy in the world' within a decade, capable of achieving sustainable economic growth, providing better jobs and ensuring social cohesion. The sustainability of the EU as an integrated economic area crucially depends on its capacity to promote convergence among countries and regions. Consequently, convergence has long been declared an objective of the EU, as formulated in Article 130a of the Single European Act in 1986, and has been 
considered a fundamental mechanism to achieve socio-economic cohesion (Alcidi et al., 2018). Despite all these efforts to promote real convergence, the empirical literature still finds a lack of real convergence between EU countries. Monfort et al. (2013) conclude that for the EU-14 Member States, north-western, southern and central eastern European countries have converged to different equilibrium levels (or club convergence) in income per capita. This club convergence is a possible form of conditional convergence, where economies belonging to a group of countries share similar features. Similarly, Ordóñez et al. (2015) also find club convergence in competitiveness measured as real unit labour costs, and in capital accumulation and total factor productivity. According to Monfort et al. (2018), the lack of real economic convergence can also be observed in income inequality and unemployment. Furthermore, this failure to converge goes beyond economic terms: Lafuente (2020) concludes that social cohesion indicators also exhibit club convergence and reflect a multi-speed Europe.

The convergence of national educational systems has been subject to analysis in comparative education studies (Carney et al., 2012). Despite the obvious national differences, educational systems tend to become increasingly similar over time (Wiseman et al., 2014). Meyer et al. (1997) suggest that this increasing similarity can be explained by a 'Common World Educational Culture', or, in other words, by global factors. According to Dale (2000), the homogenisation of education systems and curricula can be explained by countries' desire to compete in a global economy. In contrast, Johansson and Strietholt (2019) find little evidence of global convergence, concluding that countries do not converge globally but regionally.

To the best of our knowledge, this paper constitutes the first attempt to assess the Europe 2020 strategy for the education pillar in terms of convergence across countries. Despite the fact that every country in the EU has its own national targets for both headline indicators (early leavers rate and tertiary educational attainment), progress on the achievement of the Europe 2020 strategy requires convergence. Thus, even if the EU as a whole meets its targets in 2020, the existence of a growing divide between the best and worst performing countries would cast doubt on the prospects of real economic convergence and the sustainability of the process. The existence of convergence clubs would reveal asymmetries in Member States' educational performance, pointing towards the idea of a multi-speed Europe and calling into question the sustainability of the socio-economic cohesion in the EU. We evaluate the existence of convergence clubs in the educational indicators by applying the methodology proposed by Phillips and Sul $(2007,2009)$ in which different paths of convergence can be distinguished among the various heterogeneous economies involved in a convergence process. This heterogeneity is modelled through a nonlinear time-varying factor model, which provides flexibility in studying idiosyncratic behaviours over time and in cross-section. Our empirical findings reveal the existence of convergence clubs, and points towards the idea of multi-speed transitional dynamics in Europe, calling into question the convergence in educational performance in the EU.

The remainder of the paper is organised as follows. The next section summarises the methodology. Section 3 describes the data and results, and the last section concludes.

\section{Methodology}


The time-series approach to convergence analysis can be found in the seminal papers by Carlino and Mills (1993) and Bernard and Durlauf (1995, 1996). These authors developed the concept of stochastic convergence, based on the stationarity properties of the variables under analysis. Thus, two non-stationary variables converge if there is a cointegrating relationship between them. In other words, two non-stationary series converge if they share the same stochastic trend.

This definition of convergence can be empirically tested by means of time-series econometric techniques. However, as pointed out by Phillips and Sul (2009), traditional convergence tests are inadequate when technology is heterogeneous across countries and the speed of convergence is time-varying. To account for temporal and transitional heterogeneity, Phillips and Sul $(2007,2009)$ introduced cross-sectional and time-series heterogeneity in the parameters of a neoclassical growth model. The starting point for the test is the following time-varying representation:

$\mathrm{X}_{\mathrm{it}}=\delta_{\mathrm{it}} \mu_{\mathrm{t}}$

where $\mathrm{X}_{\mathrm{it}}$ is the dependent variable observed across $i=1,2, \ldots, N$ individuals over the period $\mathrm{t}=1,2, \ldots, \mathrm{T}$. $\delta_{\text {it }}$ is a idiosyncratic time-varying factor loading capturing convergence to a common factor $\mu_{t}$, which represents the common stochastic trend in the panel. In other words, $\delta_{\text {it }}$ measures the share of the common factor $\mu_{t}$ each individual in the panel experiences. The simple econometric representation in (1) can be used to analyse convergence by testing whether the factor loadings $\delta_{i t}$ converge. The idiosyncratic element is defined as:

$\delta_{i t}=\sigma_{\mathrm{i}} \varepsilon_{\mathrm{it}} \mathrm{L}(\mathrm{t})^{-1} \mathrm{t}^{-\alpha}$

where $\sigma_{\mathrm{i}}$ is fixed, $\sigma_{\mathrm{i}}>0, \varepsilon_{\mathrm{it}}$ is i.i.d $(0,1)$ across $\mathrm{i}$ but weakly dependent on $\mathrm{t}^{1}$, and $\mathrm{L}(\mathrm{t})$ is a slowly varying function for which $\mathrm{L}(\mathrm{t})$ tends to infinity as $t$ also goes to infinity.

The null hypothesis of convergence can be written as Ho: $\delta_{\text {it }}=\delta$ and $\alpha \geq 0$ against the alternative of no convergence $\mathrm{H}_{\mathrm{A}}: \delta_{\text {it }}=\delta \forall \mathrm{i}$ and $\alpha<0$. The alternative hypothesis includes divergence but can also include the possibility of club convergence. For example, if there are two convergent clubs, the alternative is:

$H_{A}: \delta_{i t} \rightarrow\left\{\begin{array}{l}\delta_{1} \text { and } \alpha \geq 0, \text { if } i \in G_{1} \\ \delta_{2} \text { and } \alpha \geq 0, \text { if } i \in G_{2}\end{array}\right.$

where $G$ stands for a specific club.

Phillips and Sul (2007) show that these hypotheses can be statistically tested by means of the following ' $\log (t)$ ' regression model:

$\log \left(\mathrm{H}_{1} / \mathrm{H}_{\mathrm{t}}\right)-2 \log (\log (\mathrm{t}))=\mathrm{a}+\mathrm{b} \log (\mathrm{t})-\mathrm{u}_{\mathrm{t}}$

\footnotetext{
${ }^{1}$ These conditions imply that the stochastic component declines asymptotically so that the trend vanishes and each coefficient converges to $\delta_{i}$.
} 
for $\mathrm{t}=[\mathrm{rT}],[\mathrm{rT}]+1, \ldots, \mathrm{T}$ with some $\mathrm{r}>0, \mathrm{~L}(\mathrm{t})=\log (\mathrm{t}+1), \hat{\mathrm{b}}=2 \hat{\mathrm{a}}$ and $\mathrm{H}_{1} / \mathrm{H}_{\mathrm{t}}$ is the cross-sectional variance ratio defined as $\mathrm{H}_{\mathrm{t}}=\frac{1}{\mathrm{~N}} \sum_{\mathrm{i}=1}^{\mathrm{N}}\left(\mathrm{h}_{\mathrm{it}}-1\right)^{2}$ and $\mathrm{h}_{\mathrm{it}}=\frac{\mathrm{x}_{\mathrm{it}}}{\frac{1}{\mathrm{~N}} \sum_{\mathrm{i}=1}^{\mathrm{N}} \mathrm{x}_{\mathrm{it}}}=$ $\frac{\delta_{\mathrm{it}}}{\frac{1}{\mathrm{~N}} \sum_{\mathrm{i}=1}^{\mathrm{N}} \delta_{\mathrm{it}}}$ which measures the loading coefficient $\delta_{\mathrm{it}}$ in relation to the panel. The variable $h_{i t}$ is called the relative transition path and traces out an individual trajectory for each i relative to the panel average. The regression is run starting at $\mathrm{t}=[\mathrm{rT}]$, which is the integer part of $r T$ for some fraction $r>0$. Phillips and Sul (2007) recommend using $\mathrm{r}=0.3$. Rejection of the null implies that there is no overall convergence, but there may be cluster convergence. The convergence patterns within groups (that is, the existence of club convergence and clustering) can be examined using log ( $t$ ) regressions. The so-called 'core group', $G_{k}$, is chosen by maximising $t_{k}$ over $k$ individuals according to the criterion:

$\mathrm{K}^{*}=\arg \max \left\{\mathrm{t}_{\mathrm{K}}\right\}$, subject to $\min \left\{\mathrm{t}_{\mathrm{k}}\right\}>-1.65$

The convergence approach proposed by Phillips and Sul (2007) presents a number of clear advantages. First, it is a test for relative convergence, as it measures convergence to some cross-sectional average, in contrast to the concept of level convergence analysed by Bernard and Durlauf (1996). Second, this approach outperforms the standard panel unit root tests, since in the latter case $X_{i t}-X_{j t}$ may retain nonstationary characteristics even though the convergence condition holds. In other words, panel unit root tests may classify the difference between gradually converging series as non-stationary. As a further problem, a mixture of stationary and non-stationary series in the panel may bias the results of unit root tests. Finally, sometimes these test results are not particularly robust. This is in contrast to the Phillips and Sul (2007) test, which does not depend on any particular assumption concerning the trend stationarity or stochastic non-stationarity of the variables to be tested.

\section{Data}

The Europe 2020 strategy indicators for the early leavers from education and training and the tertiary educational attainment rates have been taken from the Eurostat database. According to Eurostat, early leaver refers to a person aged 18 to 24 who has completed at most lower secondary education and is not involved in further education or training, while tertiary educational attainment rates correspond to International Standard Classification of Education (ISCD) levels 5 to 8 (i.e., shortcycle tertiary education, bachelor or equivalent level, and master or equivalent level). The Europe 2020 strategy sets the following benchmarks to be reached at European level by 2020: the rate of early leavers from education and training aged 18-24 should be below 10\%; and the proportion of 30-34 year-olds in Europe who have completed tertiary education should be at least $40 \%$.

The sample for the early leavers indicator covers the period 2002 to 2018 and contains Austria, Belgium, Bulgaria, Croatia, Cyprus, Czechia, Denmark, Estonia, Finland, France, Germany, Greece, Hungary, Ireland, Italy, Latvia, Lithuania, Luxembourg, Malta, the Netherlands, Poland, Portugal, Romania, Slovenia, Slovakia, Spain, Sweden, and the United Kingdom. The data for the tertiary educational attainment rate runs from 2000 to 2018, and includes Belgium, Bulgaria, Cyprus, Czechia, Denmark, Estonia, Finland, France, Germany, Greece, Hungary, 
Ireland, Italy, Latvia, Lithuania, Luxembourg, Malta, the Netherlands, Poland, Portugal, Romania, Slovenia, Slovakia, Spain, Sweden, and the United Kingdom.

Figures 1 and 2 plot the data. In the case of both indicators there is a tendency to convergence among countries in terms of a reduction in dispersion across countries when comparing the beginning and the end of the sample. However, this does not imply the existence of overall convergence. As can be seen in figure 1, a group of southern EU countries (Italy, Malta, Portugal, Spain, and Romania) present values for the early leavers rate that are above the mean for all countries throughout the whole sample. A group of eastern economies present the lowest values for the rate (Croatia, Czechia, Poland, Slovenia, and Slovakia) whereas a group of northern countries (Austria, Finland, Luxembourg, Netherlands, and Sweden) present a lower value than the panel mean for whole sample, although higher than the aforementioned group of eastern EU countries. Figure 2 shows that the lowest values in tertiary educational attainment correspond to eastern EU countries (Czechia, Estonia, Latvia, Poland, Slovenia, and Slovakia) whereas persistently higher values are recorded in southern countries (Greece, Italy, Malta, Portugal, and Spain). Looking at these graphs, it seems that there is a distinctive north-south and east-west pattern in terms of the evolution of both indicators.

Tables 1 and 2 present the descriptive statistics for the early leavers rate and the tertiary educational attainment indicators, respectively. As can be seen, both the mean value and the last observed value in 2018 present a wide disparity across countries in both ratios. In the case of the early leavers rate, the difference between the best and worst performers in 2018 - Croatia and Spain, respectively-is 14.6\%. Spain, Malta, Romania, and Italy are a long way off the $10 \%$ benchmark level for the EU, whereas Bulgaria, Hungary, and Portugal present values significantly above the target. The worst figures seem to be clustered in southern European countries. In contrast, the best performers are concentrated in both north-eastern (Lithuania and Poland) and south-eastern countries (Croatia and Slovenia), whereas north-western countries are either close to the target or well below. Regarding the tertiary educational attainment rate, only four countries have reached the EU benchmark of $40 \%$ in 2018, all of them south-western countries (Italy, Malta, Portugal, and Spain). On the other hand, Greece presents the highest rate among those countries with a tertiary educational attainment rate below $40 \%$. The worst performers in 2018 are all eastern countries (Czechia, Latvia, Lithuania, Poland, Slovenia, and Slovakia). The difference between the best and worst performers in 2018-Portugal and Czechia, respectively-is $37.7 \%$. From the analysis of the descriptive statistics for both indicators, it can be concluded that, despite a certain degree of heterogeneity, there seems to be a north-south and east-west pattern regarding the performance in both educational indicators. Therefore, the potential convergence cluster can be expected to reflect this geographical pattern.

\section{Empirical results}

The club convergence test developed by Phillips and Sul $(2007,2009)$ is applied to the two indicators early leavers from education and training and tertiary educational attainment. These authors have proven that eliminating the cyclical components of the data improves the power and size of the club convergence test in finite samples. Therefore, we have eliminated the cyclical components by means of the HP filter (Hodrick and Prescott, 1997). The test for overall panel convergence is rejected for 
both indicators with a log t-stat of -35.28 and -46.82 for the early leavers rate and the tertiary educational attainment rate, respectively. The absence of convergence for the panel leads us to consider the possible existence of club convergence.

Table 3 presents the results for the club convergence analysis. Overall convergence can be rejected in favour of club convergence, with four and six clubs for the early leavers and the tertiary educational attainment rates, respectively. For the early leavers rate, all the clubs except the first one are fairly heterogeneous in geographic terms. In contrast, the east-south pattern appears in the indicator for tertiary educational attainment: the fourth, fifth and sixth clubs are composed of eastern countries, whereas the first contains south-western economies. Given that the clustering procedure tends to find more groups than may actually exist, we have tested whether adjacent clubs can be merged into larger groups. Table 4 shows the results. According to the results, no clubs can be merged for the tertiary educational attainment rate, however, for the early leavers rate, the third and the fourth clubs can be merged, leaving three clubs in total. The final composition of clubs is shown in Table 5 .

To offer some insight into the logic behind the formation of the most heterogeneous clubs, figures 3 to 7 present the radial graphs for each of these clubs. The graphs display three values for each country belonging to the club: the initial value, in 2000 or 2002 depending on the indicator; the value in the year the Europe 2020 strategy was adopted, 2010; and the last available value, in 2018. Figure 3 shows the first convergence club for the early leavers rate indicator. This club is characterized by having values for this rate in 2018 ranging between $12 \%$ and $18 \%$. The club is entirely composed of eastern EU countries. The values registered by Hungary for this indicator are very similar at the beginning and at the end of the sample; basically, it is Spain, and to a greater extent Malta, which have converged towards the levels of the rest of the countries. Figure 4 depicts the second club, with values for the early leavers rate of between $13 \%$ and $8 \%$ for the last year of the sample. This second club is more geographically heterogeneous, containing countries from the south, north and east of the EU. As with the case of the previous club, it is the countries of southern Europe-Portugal and Bulgaria - that register the greatest reduction. The Nordic countries (Denmark, Finland and Sweden) have the lowest and most stable indicator values during the analysed period. In the third club, figure 5, the 2018 indicator values lie between $8 \%$ and $4 \%$. Austria, Slovenia and, to a lesser extent, Poland, present the most stable values throughout the sample period, levels to which the rest of the countries converge. Convergence occurs in western, eastern and southern EU countries; as such, there is no clear geographical pattern of convergence.

Figures 6 and 7 show, respectively, the radial graphs for the second and third club of the tertiary educational attainment indicator. While a significant number of countries (just under half) had a rate of about $40 \%$ or over in the year 2000 , with a mean value for the whole sample of countries of $37.4 \%$, only four countries reach this level in 2018, with a mean rate of about 24\%. Thus, figures 6 and 7 reveal poor performance: with few exceptions, there has been a decline in the tertiary educational attainment rate. The second club, shown in figure 6, presents values for 2018 of between 22\% and $29 \%$, while the third club shows values of between $18 \%$ and $24 \%$. Both clubs include countries from the south, north and east of Europe. In the second club, two countries in the south (Cyprus and Greece) and two in the north (Belgium and France) are the worst performing countries in terms of the tertiary educational attainment rate. 
For the majority of the countries in this club, most of the convergence occurs between 2000 and 2010. Regarding the third club, Ireland, which started out with a tertiary educational attainment rate of $43.7 \%$ in 2000 , suffers the most drastic decline. The United Kingdom, Hungary and Bulgaria register a similar fall in this rate, while the drop is less pronounced in Sweden. In any case, regardless of the initial level, all the countries in this club tend to converge to a level similar to that of Germany, a country that has displayed remarkable stability in its performance in relation to this rate.

Figures 8 and 9 plot the transition paths for the two education indicators of the Europe 2020 strategy. These graphs show the performance of each club relative to the panel average. Thus, a declining transition path of the corresponding indicator for a given club cannot be interpreted as a decrease in the absolute value of this indicator, but rather as a decrease in the indicator relative to the average behaviour of the whole panel, represented in the figure by the value of 1 . Therefore, these graphs are a useful way to gauge the degree of divergence among clubs and to determine when, and for how long, this divergence takes place. Divergence among clubs is clear in all three indicators. Thus, not only is there club convergence, but there is no tendency for the clubs to convergence. Early leaver and tertiary educational attainment rates show a multi-speed Europe, casting doubt on the sustainability of the overall convergence process in the EU.

\section{Conclusions}

Convergence has long been a declared objective of the EU and considered the fundamental mechanism for achieving socio-economic cohesion. In March 2010, the European Commission launched the Europe 2020 strategy 'for smart, sustainable and inclusive growth'. The education pillar of the strategy was established to ensure the development of a skilled workforce, which is considered one of the main assets of the European social and economic model. Education is a key determinant of economic growth, increasing productivity and wages. The Europe 2020 strategy established two headline targets on early leavers from education and training and tertiary educational attainment at the EU level.

This paper attempts to assess the Europe 2020 strategy for the education pillar in terms of convergence across countries. Convergence is a necessary condition for the success of the Europe 2020 strategy. Although each country has its own national target for the headline indicators, the dispersion in the early leavers from education and training and the tertiary educational attainment rates should be reduced as times goes on. Instead of overall convergence, convergence can take place in clubs, where economies belonging to the same club share similar features in terms of the education indicators and tend to a common steady state. The existence of convergence clubs indicates asymmetries in Member States' educational performance, pointing towards the idea of a multi-speed Europe and casting doubt on the sustainability of the socioeconomic cohesion in the EU. We test for the existence of clubs in the educational indicators by applying the methodology proposed by Phillips and Sul $(2007,2009)$ in which different paths of convergence can be distinguished among the various heterogeneous economies involved in a convergence process.

According to our results, overall convergence is rejected in favour of club convergence for both indicators, with three and six clubs found for the early leavers and the tertiary educational attainment rates respectively. Overall, for the early 
leavers rate, the clubs are fairly heterogeneous in geographic terms. In contrast, an east-south pattern appears in the indicator for tertiary educational attainment, with the fourth, fifth and sixth clubs being composed of eastern EU countries, whereas the first contains south-western economies. The transition paths for the various clubs in both indicators do not show any tendency to converge. Our results allow us to conclude that there is a clear difference in educational performance among the group of countries in the EU and, furthermore, this difference does not tend to decrease with time. The educational pillar of the Europe 2020 strategy has failed to promote convergence and to reduce disparities in educational performance across EU countries. 
Figure 1: Early leavers from education and training (2002-2018)

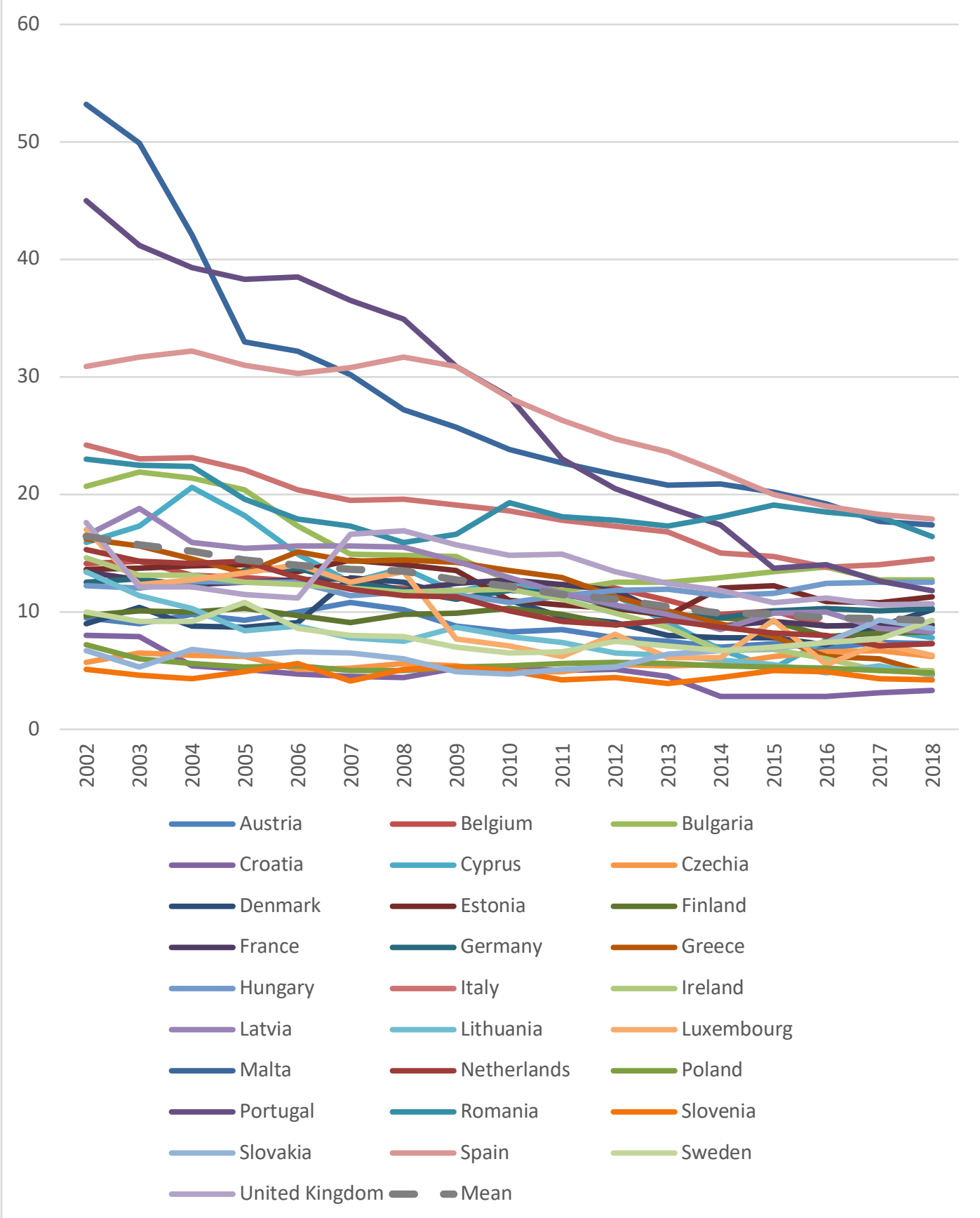


Figure 2: Tertiary educational attainment (2000-2018)

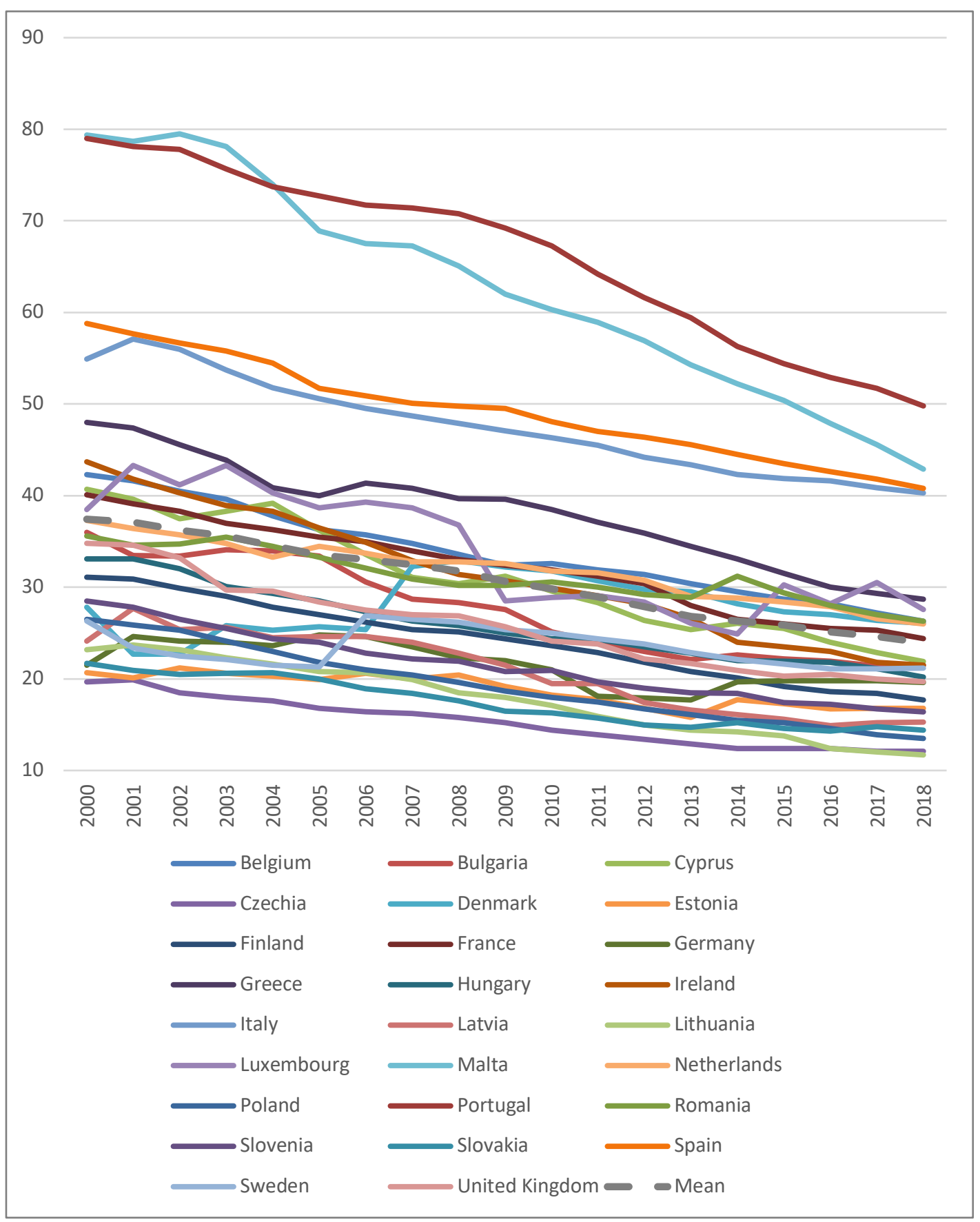


Figure 3: Radial graph early leavers from education and training: first club

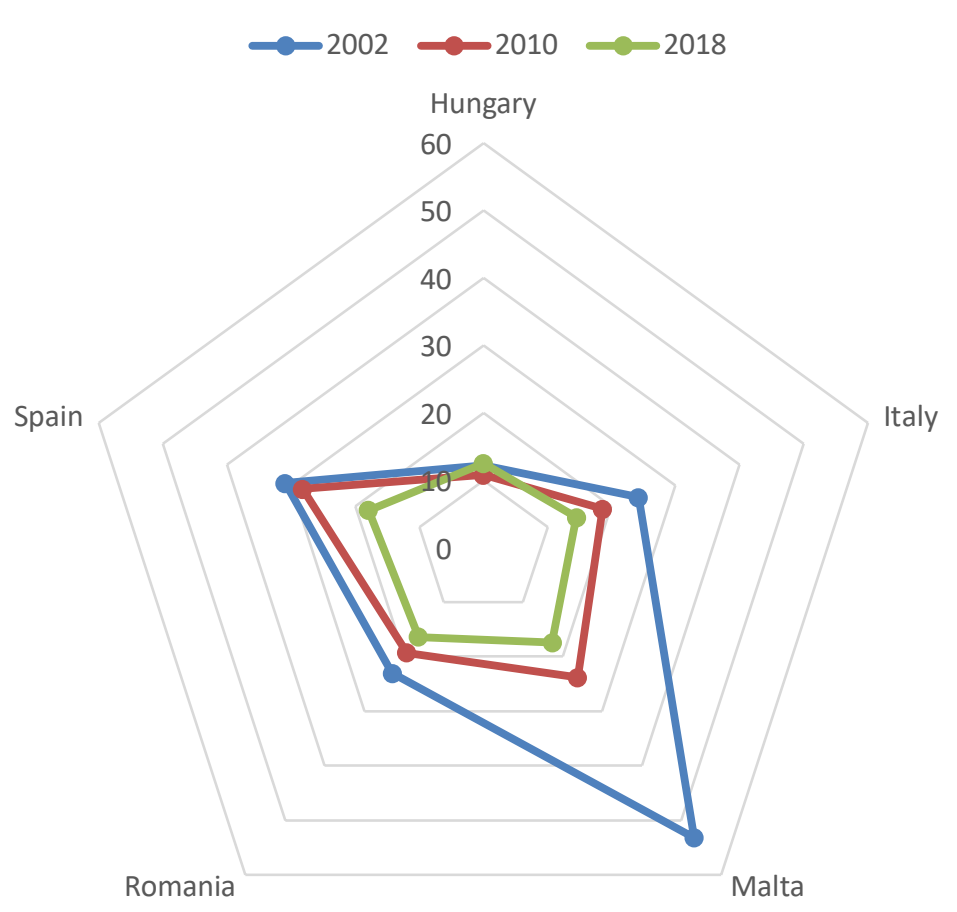


Figure 4: Radial graph early leavers from education and training: second club

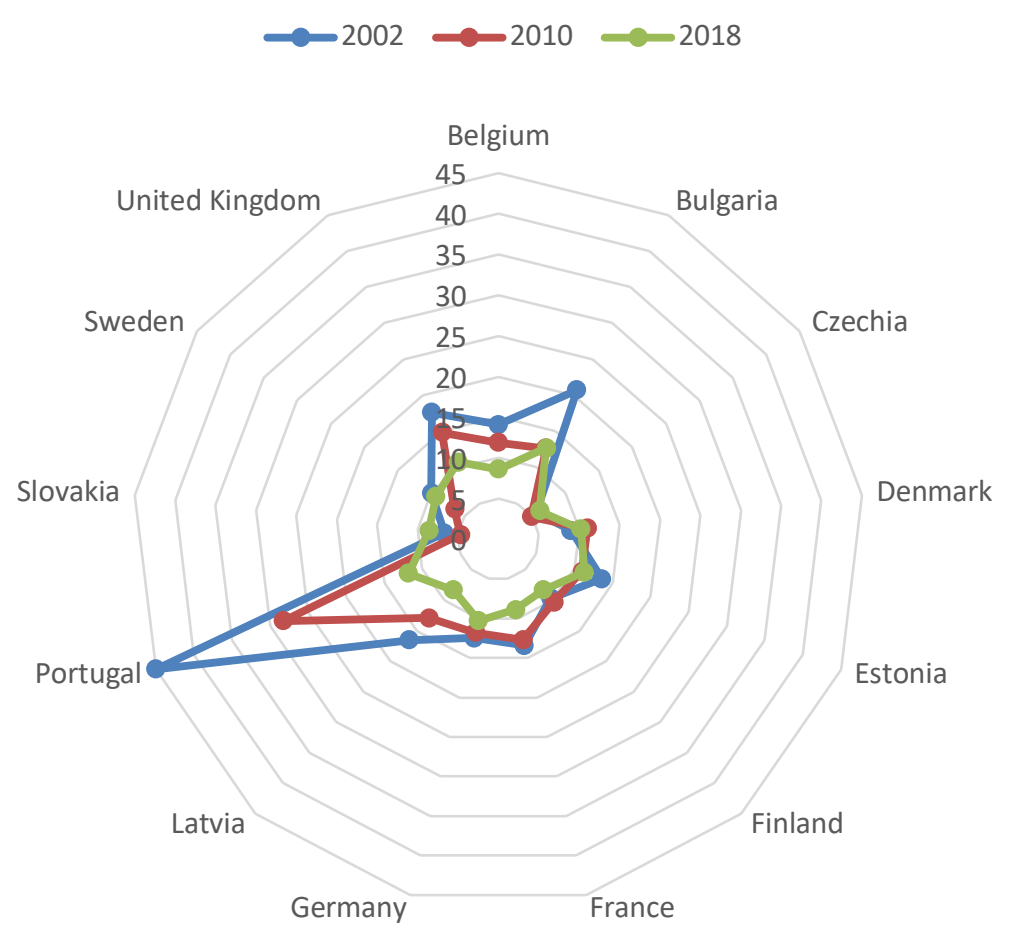


Figure 5: Radial graph early leavers from education and training: third club

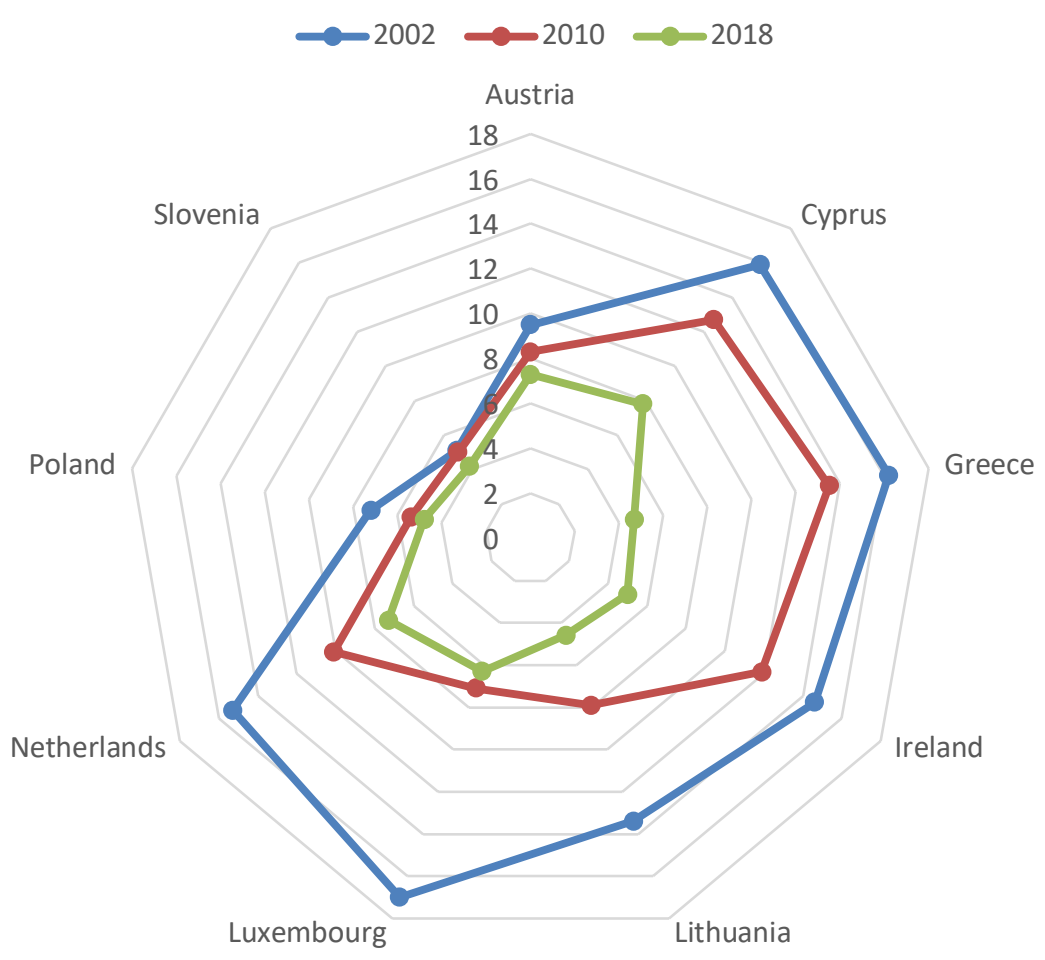


Figure 6: Radial graph tertiary educational attainment: second club

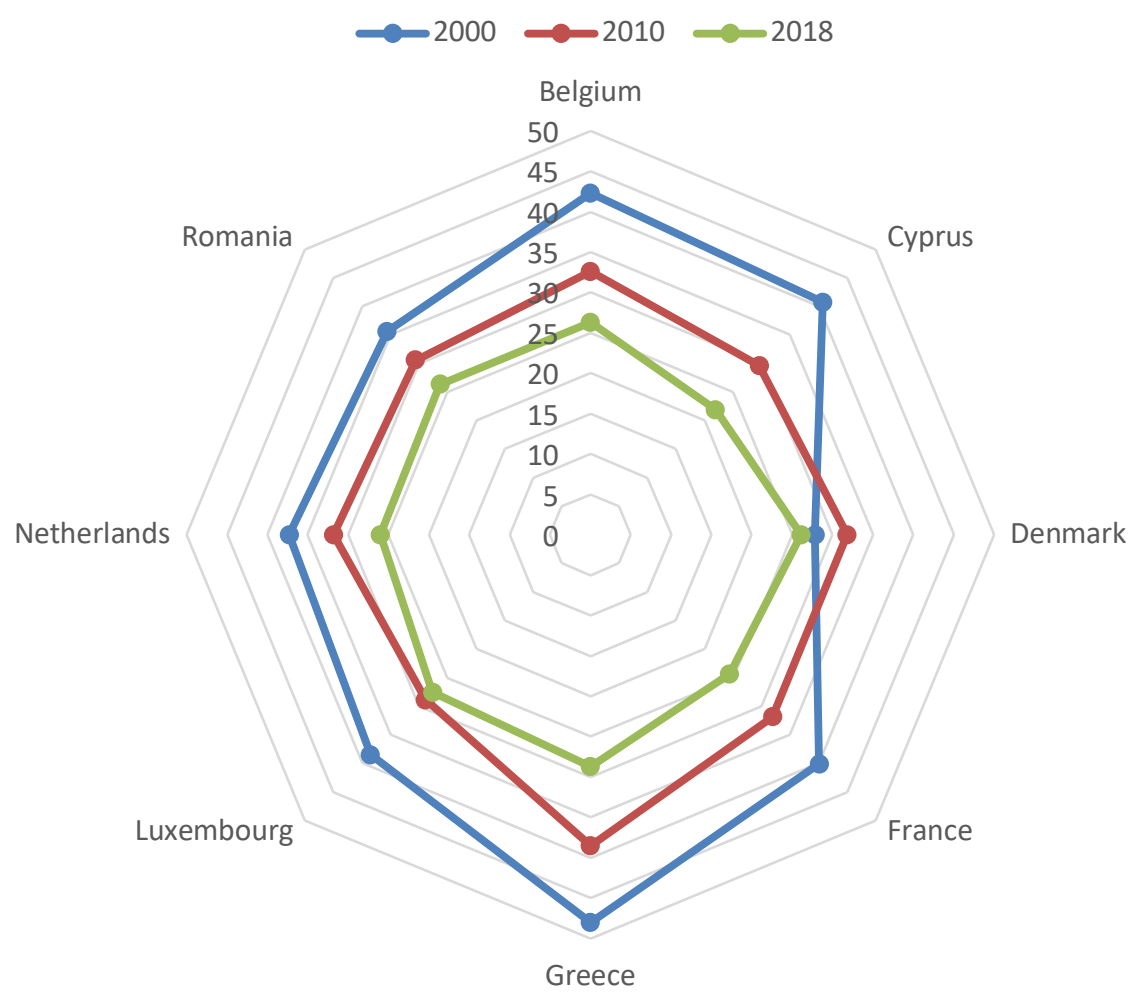


Figure 7: Radial graph tertiary educational attainment: third club

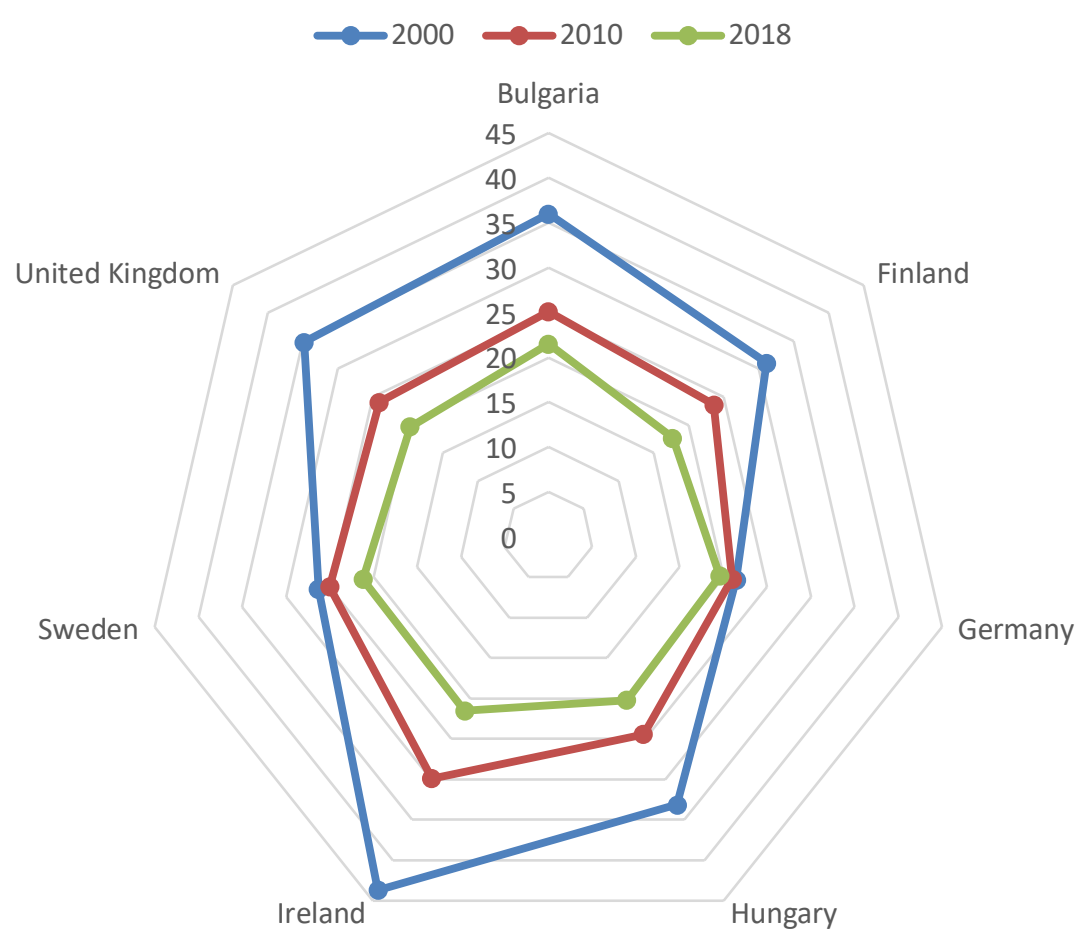


Figure 8: Clubs' transition functions: early leavers from education and training (2002-2018)

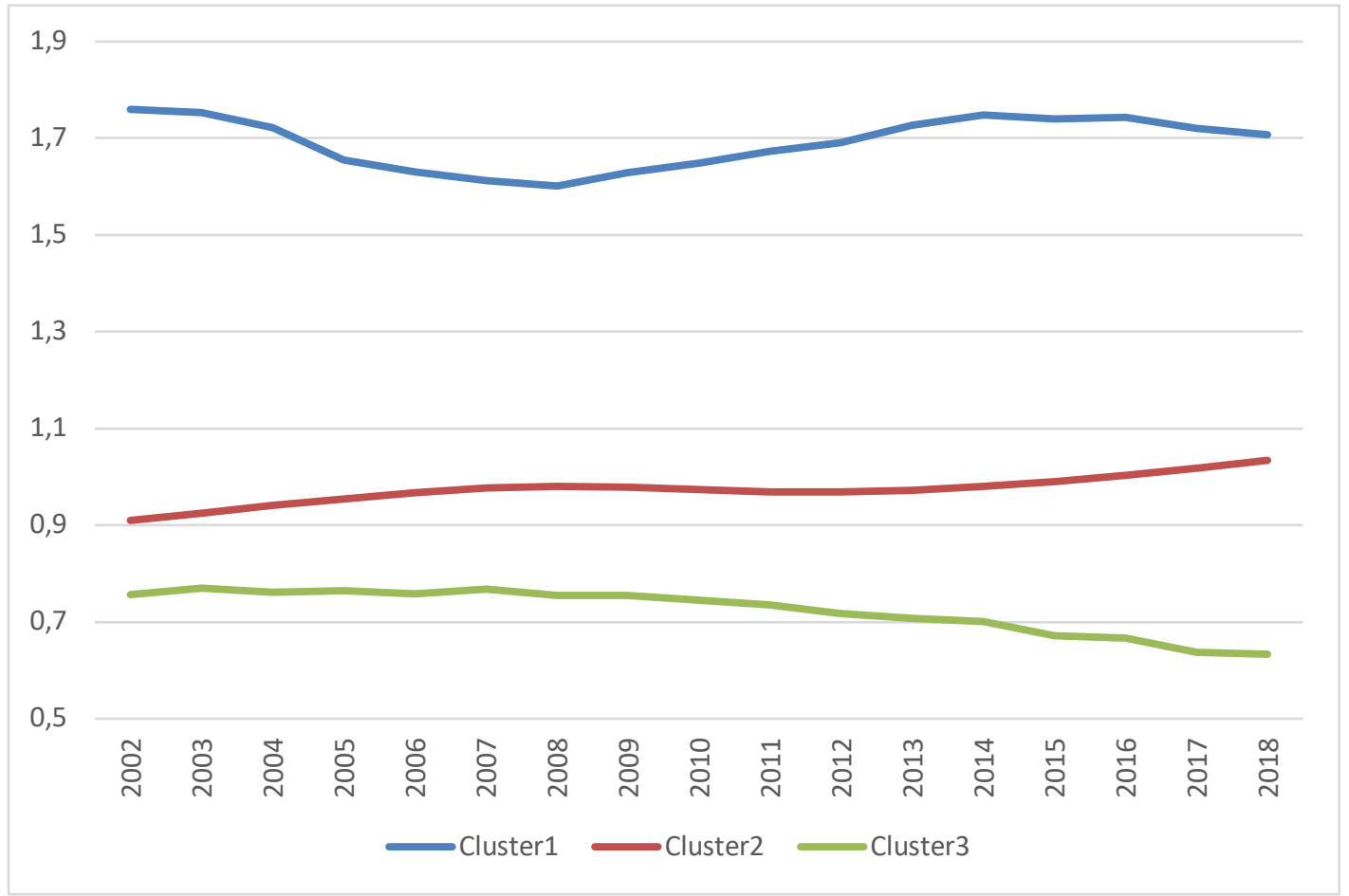


Figure 9: Clubs' transition functions: tertiary educational attainment (20002018)

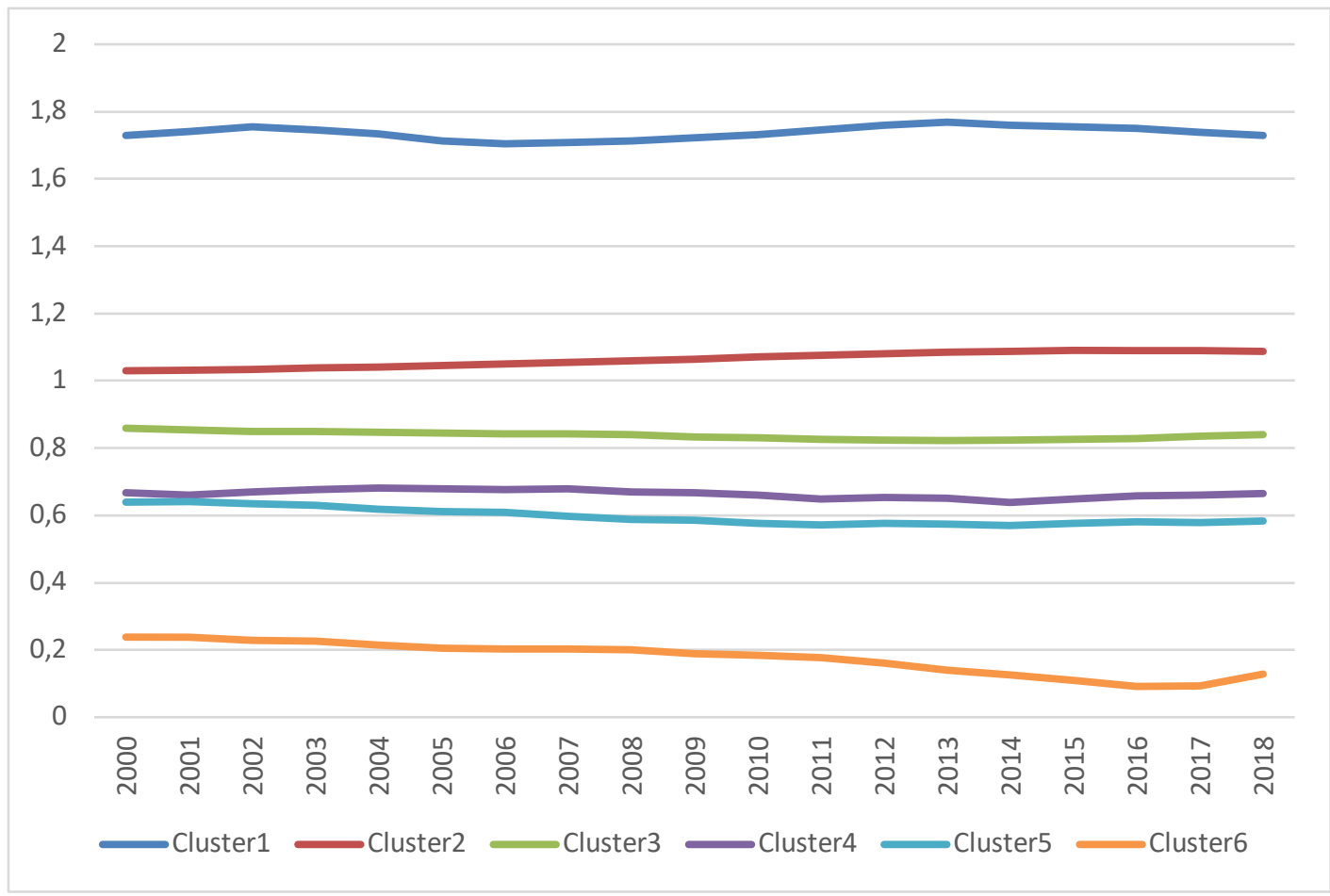


Table 1: Descriptive statistics: Early leavers from education and training (2002-2018)

\begin{tabular}{|l|c|c|c|c|c|}
\hline \multicolumn{1}{|c|}{ Country } & Mean & Std. Dev. & Min & Max & $\mathbf{2 0 1 8}$ \\
\hline Austria & 8.55 & 1.23 & 6.9 & 10.8 & 7.3 \\
\hline Belgium & 11.50 & 1.76 & 8.6 & 14.3 & 8.6 \\
\hline Bulgaria & 15.35 & 3.54 & 11.8 & 21.9 & 12.7 \\
\hline Croatia & 4.69 & 1.54 & 2.8 & 8 & 3.3 \\
\hline Cyprus & 12.07 & 4.32 & 5.2 & 20.6 & 7.8 \\
\hline Czechia & 5.75 & 0.59 & 4.9 & 6.7 & 6.2 \\
\hline Denmark & 9.54 & 1.63 & 7.2 & 12.9 & 10.2 \\
\hline Estonia & 12.31 & 1.57 & 9.7 & 14.4 & 11.3 \\
\hline Finland & 9,41 & 0.72 & 7.9 & 10.3 & 8.3 \\
\hline France & 11.27 & 1.74 & 8.8 & 13.4 & 8.9 \\
\hline Germany & 11.41 & 1.31 & 9.5 & 13.7 & 10.3 \\
\hline Greece & 11.71 & 3.69 & 4.7 & 16.2 & 4.7 \\
\hline Hungary & 11.92 & 0.53 & 10.8 & 12.6 & 12.5 \\
\hline Italy & 18.44 & 3.38 & 13.8 & 24.2 & 14.5 \\
\hline Ireland & 10.12 & 3.11 & 5 & 14.6 & 5 \\
\hline Latvia & 12.81 & 3.34 & 8.3 & 18.8 & 8.3 \\
\hline Lithuania & 7.68 & 2.37 & 4.6 & 13.4 & 4.6 \\
\hline Luxembourg & 9.7 & 3.61 & 5.5 & 17 & 6.3 \\
\hline Malta & 28.11 & 10.92 & 17.4 & 53.2 & 17.4 \\
\hline Netherlands & 10.73 & 2.68 & 7.1 & 15.3 & 7.3 \\
\hline Poland & 5.45 & 0.53 & 4.8 & 7.2 & 4.8 \\
\hline Portugal & 27.34 & 11.46 & 11.8 & 45 & 11.8 \\
\hline Romania & 18.7 & 2.12 & 15.9 & 23 & 16.4 \\
\hline Slovenia & 4.66 & 0.48 & 3.9 & 5.6 & 4.2 \\
\hline Slovakia & 6.44 & 1.23 & 4.7 & 9.3 & 8.6 \\
\hline Spain & 26.43 & 5.32 & 17.9 & 32.2 & 17.9 \\
\hline Sweden & 8.02 & 1.27 & 6.5 & 10.8 & 9.3 \\
\hline United & 13.19 & 2.38 & 10.6 & 17.6 & 10.7 \\
Kingdom & & & & & \\
\hline & & & & & \\
\hline
\end{tabular}


Table 2: Tertiary educational attainment (2000-2018)

\begin{tabular}{|l|c|c|c|c|c|}
\hline \multicolumn{1}{|c|}{ Country } & Mean & Std. Dev. & Min & Max & $\mathbf{2 0 1 8}$ \\
\hline Belgium & 33.72 & 4.93 & 26.3 & 42.3 & 26.3 \\
\hline Bulgaria & 27.54 & 5.26 & 21.4 & 36 & 21.5 \\
\hline Cyprus & 30.94 & 6.13 & 21.9 & 40.7 & 21.9 \\
\hline Czechia & 15.26 & 2.64 & 12.1 & 19.9 & 12.1 \\
\hline Denmark & 27.87 & 3.11 & 22.7 & 32.9 & 26.1 \\
\hline Estonia & 18.77 & 1.75 & 15.8 & 21.2 & 16.8 \\
\hline Finland & 24.20 & 4.36 & 17.7 & 31.1 & 17.7 \\
\hline France & 32.1 & 5.03 & 24.4 & 40.1 & 24.4 \\
\hline Germany & 21.49 & 2.43 & 17.7 & 24.8 & 19.6 \\
\hline Greece & 38.20 & 5.90 & 28.7 & 48 & 28.7 \\
\hline Hungary & 25.92 & 4.10 & 20.2 & 33.1 & 20.2 \\
\hline Ireland & 31.42 & 7.07 & 21.5 & 43.7 & 21.5 \\
\hline Italy & 47.56 & 5.33 & 40.3 & 57.1 & 40.3 \\
\hline Latvia & 20.78 & 4.33 & 14.9 & 27.2 & 15.3 \\
\hline Lithuania & 17.81 & 4.10 & 11.7 & 23.7 & 11.7 \\
\hline Luxembourg & 33.82 & 6.33 & 24.9 & 43.3 & 27.6 \\
\hline Malta & 62.62 & 11.92 & 42.9 & 79.5 & 42.9 \\
\hline Netherlands & 31.83 & 3.30 & 26 & 37.3 & 26 \\
\hline Poland & 19.33 & 4.19 & 13.5 & 26.5 & 13.5 \\
\hline Portugal & 66.19 & 9.66 & 49.8 & 79 & 49.8 \\
\hline Romania & 31.16 & 2.84 & 26.3 & 35.6 & 26.3 \\
\hline Slovenia & 21.50 & 3.80 & 16.4 & 28.5 & 16.4 \\
\hline Slovakia & 17.41 & 2.66 & 14.3 & 21.7 & 14.4 \\
\hline Spain & 49.25 & 5.54 & 40.8 & 58.8 & 40.8 \\
\hline Sweden & 23.43 & 2.06 & 21.2 & 26.9 & 21.2 \\
\hline United & 25.82 & 4.97 & 19.7 & 43.8 & 19.7 \\
Kingdom & & & & & \\
\hline
\end{tabular}


Table 3: Club analysis

\begin{tabular}{|c|c|c|}
\hline \multicolumn{3}{|c|}{ Early leavers from education and training $(2002-2008)$} \\
\hline $\log t$ & t statistic & Clubs \\
\hline 0.178 & 1.297 & $\begin{array}{l}\text { First club: } \\
\text { Hungary, Italy, Malta, Romania, and Spain }\end{array}$ \\
\hline 0.205 & 1.214 & $\begin{array}{l}\text { Second club: } \\
\text { Belgium, Bulgaria, Czechia, Denmark, Estonia, Finland, } \\
\text { France, Germany, Latvia, Portugal, Slovakia, Sweden, and } \\
\text { the United Kingdom }\end{array}$ \\
\hline 0.196 & 1.058 & $\begin{array}{l}\text { Third club: } \\
\text { Austria, Cyprus, Greece, Luxembourg, the Netherlands, } \\
\text { Poland }\end{array}$ \\
\hline 0.851 & 2.352 & $\begin{array}{l}\text { Fourth club: } \\
\text { Ireland, Lithuania, and Slovenia }\end{array}$ \\
\hline- & - & $\begin{array}{l}\text { No club convergence: } \\
\text { Croatia }\end{array}$ \\
\hline \multicolumn{3}{|c|}{ Tertiary educational attainment (2000-2018) } \\
\hline $\log t$ & t statistic & Clubs \\
\hline 0.154 & 0.821 & $\begin{array}{l}\text { First club: } \\
\text { Italy, Malta, and Spain }\end{array}$ \\
\hline-0.090 & -1.482 & $\begin{array}{l}\text { Second club: } \\
\text { Belgium, Cyprus, Denmark, France, Greece, Luxembourg, } \\
\text { the Netherlands, and Romania }\end{array}$ \\
\hline 0.049 & 0.387 & $\begin{array}{l}\text { Third club: } \\
\text { Bulgaria, Finland, Germany, Hungary, Ireland, Sweden, } \\
\text { and the United Kingdom }\end{array}$ \\
\hline 0.074 & 0.478 & $\begin{array}{l}\text { Fourth club: } \\
\text { Estonia, Latvia, and Slovenia }\end{array}$ \\
\hline 1.839 & 1.709 & Fifth club: \\
\hline 1.211 & 2.522 & $\begin{array}{l}\text { Sixth club: } \\
\text { Czechia and Lithuania, }\end{array}$ \\
\hline - & - & $\begin{array}{l}\text { No club convergence: } \\
\text { Portugal, }\end{array}$ \\
\hline
\end{tabular}


Table 4: Testing for club merging

\begin{tabular}{|c|c|l|}
\hline \multicolumn{3}{|c|}{ Early leavers from education and training (2002 - } \\
\hline \multicolumn{3}{|c|}{ 2008) } \\
\hline Log t & t statistic & \multicolumn{1}{c|}{ Clubs } \\
\hline-0.307 & -3.054 & Club $1+2$ \\
\hline-0.265 & -2.254 & Club $2+3$ \\
\hline-0.061 & -0.427 & Club 3+4 \\
\hline-0.589 & -6.844 & Club 4+5 \\
\hline \multicolumn{3}{|c|}{} \\
\hline \multicolumn{3}{|c|}{ Tertiary educational attainment (2000-2018) } \\
\hline \multicolumn{3}{|c|}{ Clubs } \\
\hline Log t & t statistic & \multicolumn{1}{|c|}{} \\
\hline-0.838 & -27.549 & Club $1+2$ \\
\hline-0.872 & -38.395 & Club 2+3 \\
\hline-0.657 & -24.344 & Club 3+4 \\
\hline-0.729 & -15.479 & Club 4+5 \\
\hline-0.795 & -11.523 & Club 5+6 \\
\hline-1.301 & -38.193 & Club $6+7$ \\
\hline
\end{tabular}


Table 5: Final club analysis

\begin{tabular}{|c|c|l|}
\hline \multicolumn{3}{|c|}{ Early leavers from education and training (2002 - 2008) } \\
\hline Log t & t statistic & \multicolumn{1}{c|}{ Clubs } \\
\hline 0.178 & 1.297 & $\begin{array}{l}\text { First club: } \\
\text { Hungary, Italy, Malta, Romania, and Spain }\end{array}$ \\
\hline 0.205 & 1.214 & $\begin{array}{l}\text { Second club: } \\
\text { Belgium, Bulgaria, Czechia, Denmark, Estonia, Finland, } \\
\text { France, Germany, Latvia, Portugal, Slovakia, Sweden, and } \\
\text { the United Kingdom }\end{array}$ \\
\hline-0.061 & -0.427 & $\begin{array}{l}\text { Third club: } \\
\text { Austria, Cyprus, Greece, Ireland, Lithuania, Luxembourg, } \\
\text { the Netherlands, Poland, and Slovenia }\end{array}$ \\
\hline- & - & $\begin{array}{l}\text { No club convergence: } \\
\text { Croatia }\end{array}$ \\
\hline
\end{tabular}




\section{References}

Alcidi, C., Núñez Ferrer, J., Di Salvo, M., Musmeci., R., and Pilati, M. (2018) Income convergence in the EU: A tale of two speeds, CEPS commentary, January $8^{\text {th }}$. Acemoglu, D., and Pischke, J.S. (2001) Changes in the wage structure, family income, and children's education, European Economic Review, 45, 890-904.

Becker, G.S. (1964) Human Capital, New York: Columbia University Press for the National Bureau of Economic Research.

Becker, G.S., and Tomes, N. (1979). An Equilibrium Theory of the Distribution of Income and Intergenerational Mobility, Journal of Political Economy, 87, 1153-89

Becker, G.S. and Tomes, N. (1986) Human Capital and the Rise and Fall of Families, Journal of Labour Economics, 4, S1-S39

Bernard, A.B. and Durlauf, S. N. (1995) Convergence in International Output, Journal of Applied Econometrics, 10, 97-108.

Bernard, A.B. and Durlauf, S. N. (1996) Interpreting Tests of Convergence Hypothesis, Journal of Econometrics, 71, 161-173.

Black, S. E., and Devereux, P. J. (2011) Recent developments in intergenerational mobility. In O. Ashenfelter, and D. Card (Eds.), Handbook of labour economics, 4, 1487-1541.

Carlino, G., and Mills, L. (1993) Are US Incomes Converging? A Time Series Analysis, Journal of Monetary Economics, 32, 335-346.

Carney, S., Rappleye, J., and Silova, I. (2012) Between Faith and Science: World Culture Theory and Comparative Education, Comparative Education Review $56,366-393$.

Dale, R. (2000) Globalization and Education: Demonstrating a 'Common World Educational Culture' or Locating a 'Globally Structured Educational Agenda'?', Educational Theory, 50, 427-448.

European Commission (2010) Europe 2020. A strategy for smart, sustainable and inclusive growth, 3 March, Brussels.

Furlong, A. (2006) Not a very NEET solution: representing problematic labor market transitions among early school-leavers, Work, Employment and Society, 20, $553-569$. 
Heckman, J.J. (1976) A Life-Cycle Model of Earnings, Learning, and Consumption, Journal of Political Economy, 84, S11-S44.

Hodrick, R.J. and Prescott, E.C. (1997) Postwar U.S. Business Cycles: An Empirical Investigation, Journal of Money, Credit and Banking, 29, 1-16.

Johansson, S. and Strietholt, R. (2019) Globalised student achievement? A longitudinal and cross-country analysis of convergence in mathematics performance, Comparative Education, 55, 536-556.

Keane, M.P. and Wolpin, K.I. (1997) The career decisions of young men, Journal of Political Economy, 105, 473-522.

Lafuente, J.A., Marco, A., Monfort, M., and Ordóñez, J. (2020) Social exclusion and convergence in the EU: an assessment of the Europe 2020 strategy, mimeo.

Mankiw, G., Romer, D., and Weil, D. (1992) A Contribution to the Empirics of Economic Growth, Quarterly Journal of Economics, 107, 407-438.

Meyer, J. W., Boli, J., Thomas, G. M. and Ramirez, F. O. (1997) World Society and the Nation-State, American Journal of Sociology, 103, 144-181.

Monfort, M., Cuestas, J.C., and Ordóñez, J. (2013) Real convergence in Europe: A cluster analysis, Economic Modelling, 33, 689-694.

Monfort, M., Ordóñez, J., and Sala, H. (2018) Inequality and Unemployment Patterns in Europe: Does Integration Lead to (Real) Convergence?, Open Economies Review, 29, 703-724.

Ordóñez, J., Sala, H., and Silva, J.I. (2015) Real unit labour costs in Eurozone countries: drivers and clusters, IZA Journal of European Labor Studies, 4, 119.

Phillips, P. and Sul, D. (2007) Transition Modeling and Econometric Convergence Tests, Econometrica, 75, 1771-1855.

Phillips, P. and Sul, D. (2009) Economic Transition and Growth, Journal of Applied Econometrics, 24, 1153-1185.

Wiseman, A.W., Astiz, M.A., and Baker, D.P. (2014) Comparative Education Research Framed by neo-Institutional Theory: A Review of Diverse Approaches and Conflicting Assumptions. Compare: A Journal of Comparative and International Education, 44, 688-709. 